\title{
HOUSING ATTRIBUTES AND THE COST OF PRIVATE RENTAL BUILDINGS IN LAGOS NIGERIA: A HEDONIC PRICE ANALYSIS
}

\author{
Uchenna N. Akpom*
}

\begin{abstract}
While the hedonic analysis has been used extensively to analyze the housing markets in developed countries, it has relatively few applications to African housing markets. The need to study housing markets in Africa cannot be overemphasized. This paper presents the results of a hedonic price analysis of the Lagos, Nigeria, housing market. A Box-Cox transformation technique was employed for the analysis. Implicit prices for housing attributes were estimated to determine their impacts on rental rates in Lagos. The results indicate that both structural and environmental characteristics of a house affect its rent in Lagos. Further, structural characteristics appear to be more important than environmental characteristics in the market studied. These results are generally similar to the results obtained for developed countries, except that environmental attributes seem to be more important in developed countries than this study shows. Some policy implications of the hedonic analysis are briefly discussed.
\end{abstract}

\section{INTRODUCTION}

Although the hedonic price method has often been employed in studying the market for housing in developed countries, this has not been true in less developed countries. A few such studies, however, do deal with Asian and Latin American countries (Follain, Lim, and Renaud 1980), and (Follain and Jimenez 1985b). On the other hand, little research has been done on African countries.

Recently, many African cities have experienced rapid growth (see Onokerhoraye 1976, Lubell 1984, and Malpezzi and Mayo 1987). The "housing revolution" that followed this growth points to the importance of studies directed toward housing problems in Africa. In addition, the importance of studies dealing with housing markets in Africa is even greater when one considers that these markets revolve around the role of the various governments in the housing markets, resulting in rent controls, direct provision of housing and infrastructures, and poor planning. Thus the nature of housing markets in Africa suggests difficulties with applying results based on the developed countries to Africa.

Okpala (1987) suggests that different models may be needed to analyze housing markets in less developed countries. While factors such as school structural quality and environmental factors such as heating problems may be important in most western European countries, they may not be important in most

*Associate Professor of Economics, University of West Alabama. 
African countries because residential location does not determine school attendance, in most cases. Also, given the differences in weather conditions, heating which has been an important element in the United States (Michaels and Smith 1990) may not be important in many African countries. This paper utilizes hedonic price indexes to examine the effects of structural and environmental characteristics on the cost of private rental housing in a large Nigerian urban area.

This study is limited by a few factors, the most obvious one being that surveys conducted in less developed countries tend to be suspect. While efforts were made to obtain unbiased data, the problems of respondent and interviewer bias cannot be completely ruled out. Secondly, the method used to collect data was not completely random because of the high cost involved. Every effort was made, however to make the study as random as possible. Finally, this study is based on data from only one city that might not necessarily represent an average Nigerian city. Therefore the results obtained may not be applicable to other cities.

\section{The Nigerian Housing Market}

The housing market in Nigeria can be divided into two major sectors: the public sector and the private sector. Most of the publicly supplied housing is provided by the federal, state, and local governments. Though the role of the government has increased over the years, it is estimated that the total stock of housing supplied by the government represents less than 5 percent of the housing stock in the country (Megbolugbe 1986).

Houses in the private sector, on the other hand, are provided by private individuals, businesses and charitable organizations. Most of the houses are owned by members of households who themselves occupy a flat in the building (or rooms, in the case of rooming buildings), and offer the remainder of the building for rent.

This study is limited to the private housing market, of which two different types can be identified-the traditional and the non-traditional houses.

Traditional houses reflect the traditional, cultural, religious and environmental aspects of the different tribal groups that make up the country. While the houses are similar in some cases, there exist some basic differences in various areas of the country. These differences can be attributed to local customs and traditions, the need for privacy, the skills and building materials available, and the stage of family growth.

Traditional houses are generally walled, with a number of separate houses built inside the compound. The walls of the houses are made of mud, and the roofs are made of thatch from palm leaves or long grass. Compounds are usually 
occupied by more than one household, the members of which are closely related. Visitors are usually first received in a reception hall.

The windows of traditional houses are usually square or circular in shape and many are uncurtained. In others, a wooden cover is used. The kitchen, toilet, and bathroom are usually detached from the main building. The traditional houses most common in rural areas are not the emphasis of this study.

Non-traditional houses are usually concentrated in urban areas and major towns. They are similar in most cases to houses found in many developed countries. In fact, the materials used to build these houses are copied or imported from developed countries in most cases. Many of the houses are built, not only for the occupancy of a single family, but also for rent to other tenants.

In addition, most non-traditional houses are made of cement walls, with roofs of corrugated iron sheets. The windows are usually bigger than those of traditional houses and are normally covered with wooden or glass coverings that allow the windows to be opened or shut. The walls are generally painted, though some landlords paint only the inside of the buildings before renting them out.

This paper focuses on non-traditional houses in Lagos, Nigeria, a major urban city. Table 1 presents estimates of the number of houses in selected Nigerian cities.

\section{THEORETICAL MODEL}

A housing unit is a heterogeneous commodity, each unit being different from others because of the different attributes. When a house is purchased or rented, the various attributes that go with it are also purchased or rented. These attributes include the number of rooms, types of toilets, parking, and location or distance to important amenities.

Relationships between a housing unit and its characteristics have been studied by Lancaster (1966), who discussed the utility-bearing characteristics of a commodity, and Rosen (1974) who later extended the study to include a market between buyers and sellers to obtain the equilibrium-implicit prices of the characteristics. Rosen's approach has been frequently used in housing demand literature.

The relationship between a housing unit and its characteristics can be represented as:

$$
H=H\left(z_{1}, z_{2}, \ldots, z_{n}\right)
$$

Where $\mathrm{H}$ represents housing units and $\mathrm{z}$ represents various housing attributes. In keeping with the literature, we assume that the price of a house is a function of the 
TABLE 1

Estimated Number of Houses in Selected Nigerian Cities

\begin{tabular}{|c|c|c|c|c|c|}
\hline \multirow[b]{2}{*}{ Towns } & \multirow[b]{2}{*}{$\begin{array}{c}\text { Estimated } \\
\text { number of } \\
\text { houses }\end{array}$} & \multirow{2}{*}{$\begin{array}{c}\text { Estimated } \\
\text { number of } \\
\text { derelict } \\
\text { buildings }\end{array}$} & \multicolumn{3}{|c|}{ Percentages } \\
\hline & & & Derelict & $\begin{array}{r}\text { Fairly } \\
\text { good }\end{array}$ & Good \\
\hline Aba & 103,000 & 10,000 & 10.0 & 60.0 & 30.0 \\
\hline Benin & 110,000 & 17,000 & 15.5 & 41.7 & 42.8 \\
\hline Calabar & 24,000 & 3,000 & 12.5 & 45.0 & 42.5 \\
\hline Enugu & 127,000 & 28,000 & 21.7 & 46.7 & 31.6 \\
\hline Ibadan & 355,000 & 64,000 & 18.0 & 50.0 & 32.0 \\
\hline Jos & 72,000 & 19,000 & 26.4 & 36.6 & 37.0 \\
\hline Kano & 235,000 & 24,000 & 10.2 & 22.5 & 67.3 \\
\hline Lagos & 645,000 & 103,000 & 16.1 & 55.8 & 23.1 \\
\hline Makurdi & 16,000 & 1,900 & 11.9 & 53.3 & 34.8 \\
\hline Onitsha & 176,000 & 7,000 & 4.0 & 43.1 & 52.9 \\
\hline Owerri & 24,000 & 4,000 & 16.7 & 44.0 & 39.3 \\
\hline Port-Harcourt & 156,000 & 37,000 & 23.7 & 55.0 & 21.3 \\
\hline Sokoto & 88,000 & 4,400 & 5.0 & 75.0 & 20.0 \\
\hline Yola & 12,000 & 3,800 & 31.7 & 56.1 & 12.2 \\
\hline
\end{tabular}

Source: Federal Mortgage Bank of Nigeria Journal, 1(1986) P. 9.

attributes of the house. The more utility-bearing attributes a house offers, the more consumers are willing to pay for the house. Therefore, a relationship exists between the rent paid for a house and the various attributes of the house, which can be expressed as:

$$
R(Z)=R\left(z_{1}, z_{2}, \ldots, z_{n}\right)
$$

where $\mathrm{R}$ is the rental rate of the house and the $\mathrm{zs}$ are as defined in equation (1) above. Classifying the attributes into structural (S), locational (L), and neighborhood (N) attributes implies that equation (2) can be written as:

$$
R=. f(S, L, N)
$$

Estimates of the relationships can be obtained using regression analysis. Partially differentiating equation (2) with respect to any attribute, assuming other attributes remain constant, gives the marginal price of that attribute hence: 


$$
\partial \mathrm{R}(\mathrm{z}) / \partial \mathrm{z}_{\mathrm{i}}=\mathrm{P}_{\mathrm{i}}
$$

where $\mathrm{P}_{\mathrm{i}}$ is the price of the ith attribute, referred to as its implicit price.

\section{EMPIRICAL MODEL}

Hedonic price analysis of the housing market assumes a relationship between the price of a housing unit and the attributes of the unit. Using a well-specified function, it is possible to obtain the effects of these attributes on the price of the housing unit. A problem with estimating the hedonic function has always been the selection of an appropriate functional form (Dubin and Sung 1990). There does not seem to be a theoretical basis for choosing one form over others (Halvorsen and Pollakowski 1981).

Many studies have used the linear, log-linear, and semi-log forms to analyze housing markets, for example (Palmquist 1984) and (Kain and Quigley 1970). Other studies such as Blomquist (1988) and Halvorsen and Pollakowski (1981) rejected these functional forms. Blomquist and Worley (1982) however, found the $\log$ form not to be significantly different from their best form at the 5 percent level.

Box and Cox (1964) provides a functional form that allows other forms to be obtained by imposing restrictions on the transformation parameters. This flexible form has been heavily used in the housing literature. A few examples include Linneman (1980), Cassel and Mandelsohn (1985), Goodman and Kawia (1986), Blomquist (1988), Megbolugbe (1986), and Dinan and Miranowski (1989). This paper utilizes the Box-Cox transformation of the form:

$$
R(\lambda)=\alpha+\Sigma \beta_{i} S_{i}(\mu)+\Sigma \tau_{i} E_{i}(\mu)+\epsilon_{i}
$$

where $\mathrm{R}$ is the monthly contract rent on the housing unit, $\mathrm{S}$ is the structural attribute, $\mathrm{E}$, the environmental attribute, and $\epsilon$ is the error term. Locational and neighborhood attributes $L$ and $N$ in equation (3) are combined to obtain $\alpha, \beta, \tau$. $\lambda$ and $\mu$ are the power transformation parameters on the dependent and independent variables, respectively. $R(\lambda), S_{i}(\mu), E_{i}(\mu)$ are the Box-Cox transformations:

$$
\begin{array}{rlr}
R(\lambda)= & \left(\mathbf{R}^{\lambda}-1\right) / \lambda & \lambda \neq 0 \\
& \ln R^{2} & \lambda=0 \\
S_{i}(\mu)= & \left(S_{i}^{\mu}-1\right) / \mu & \mu \neq 0 \\
& \ln S_{i} & \mu=0
\end{array}
$$




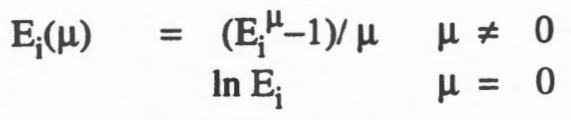

Using the restriction $\lambda=\mu=0$, the log-linear form can be obtained, since the limit for $\lambda \neq 0$, and $\mu \neq 0$ as $\lambda$, and $\mu \rightarrow 0$ are $\ln R, \ln S_{i}$, and $\ln E_{i}$, (Halvorsen and Pollakowski 1981). Other functional forms can be derived by rewriting equation (5):

$$
\begin{aligned}
& \mathbf{R}^{\lambda-1}=\lambda\left[\alpha+\Sigma \beta_{i}\left\{\left(S_{i}{ }^{\mu}-1\right) / \mu\right\}+\Sigma \tau_{i}\left\{\left(E_{i}{ }^{\mu}-1\right) / \mu\right\}+\epsilon_{i}\right] \\
& R=\left\{1-\lambda\left[\alpha+\Sigma \beta_{i}\left\{\left(S_{i}{ }^{\mu}-1\right) / \mu\right\}+\Sigma \tau_{i}\left\{\left(E_{i}{ }^{\mu}-1\right) / \mu\right\}+\epsilon_{i}\right]\right\}^{(1 / \lambda)}
\end{aligned}
$$

Setting $\lambda=\mu=1$ gives the linear form:

$$
R=\alpha^{\prime}+\Sigma \beta_{i} S_{i}+\Sigma \tau_{i} E_{i}+\epsilon_{i}
$$

where $\alpha^{\prime}=1+\alpha-\left(\Sigma \beta_{i}+\Sigma \tau_{i}\right)$

The semi-log form can be obtained if the restriction $\lambda=0$, and $\mu=1$ are used. Maximizing the log-likelihood function of equation (5) gives the best estimates of the transformation parameters, hence, the best functional form.

Several functional forms were estimated, but the best form, based on the maximum likelihood test, was used to analyze the housing market. Due to the difficulty with applying a full search for the transformation parameters, a limited search was conducted for this paper. For instance, in a full search, the values of $\mu_{i}$ could be different for each $S_{i}$ and $E_{i}$.

\section{THE DATA}

Data for this study were obtained from a special survey of 929 private residents of Lagos, Nigeria, in the summer of 1988. The survey was conducted specifically for our study by Harriman and Co., Ibadan, a group of real estate consultants, and the author. The definition variables and summary statistics are presented in Table 2.

A sample of 1,200 housing units was initially selected for the interview, but only 826 usable responses were used for the study. A three-step sampling method was used. The streets were first selected, then the housing units, and finally the households. The first street was randomly selected from a comprehensive street map of Lagos, then a systematic method was used to select the remaining streets. 
TABLE 2

Definition of Variables and Summary Statistics for Housing Hedonic Estimation for Lagos, Nigeria

\begin{tabular}{|c|c|c|c|}
\hline Variables & Description & Means & $\begin{array}{l}\text { Standard } \\
\text { deviation }\end{array}$ \\
\hline RENT & Monthly contract rent in Nigerian naira & 365.30 & 673.50 \\
\hline BDGRM & 1 if rooming house & 0.26 & 0.44 \\
\hline BDGFLT & 1 if flats & 0.61 & 0.49 \\
\hline NROOM & Number of rooms rented & 2.56 & 1.87 \\
\hline BATH & $\begin{array}{l}\text { Number of bathrooms. Measured as a bathroom } \\
\text { and toilet }\end{array}$ & 0.76 & 1.02 \\
\hline KITCH & 1 if private kitchen & 0.42 & 0.49 \\
\hline NFLAT & Number of flats in the building & 2.25 & 3.15 \\
\hline NFLOOR & $\begin{array}{l}\text { Number of floors in the building counting the } \\
\text { ground floor as one }\end{array}$ & 1.61 & 0.69 \\
\hline FENCE & 1 if building is fenced & 0.71 & 0.45 \\
\hline MKT & $\begin{array}{l}\text { Distance in kilometers to the nearest major } \\
\text { market center }\end{array}$ & 1.94 & 1.26 \\
\hline WORK & $\begin{array}{l}\text { Distance in kilometers to the place of work of } \\
\text { the major income earner of the household }\end{array}$ & 8.18 & 7.08 \\
\hline CBD & Distance (kilometers) to Lagos Island & 8.58 & 1.91 \\
\hline CRIME & $\begin{array}{l}\text { Ranking by crime rate ( } 1 \text { for lowest to } 8 \text { for } \\
\text { the highest) }\end{array}$ & 3.81 & 2.16 \\
\hline ELECOC & 1 if supply of electricity to building is occasional & 0.73 & 0.44 \\
\hline ELECST & 1 if supply of electricity is steady & 0.19 & 0.39 \\
\hline WATOC & 1 if pipe-borne water supply is occasional & 0.33 & 0.47 \\
\hline WATST & 1 if pipe-borne water supply is steady & 0.26 & 0.44 \\
\hline PAINTPT & 1 if building is partially painted & 0.10 & 0.36 \\
\hline PAINTFL & 1 if building is fully painted & 0.84 & 0.37 \\
\hline STRFAIR & $\begin{array}{l}1 \text { if street on which the building is located is } \\
\text { in fair condition }\end{array}$ & 0.40 & 0.49 \\
\hline STRGOOD & 1 if street is in good condition & 0.26 & 0.44 \\
\hline STREXC & 1 if street is in excellent condition & 0.14 & 0.34 \\
\hline BDGFAIR & $\begin{array}{l}1 \text { if surrounding buildings at the location are } \\
\text { in fair condition }\end{array}$ & 0.40 & 0.49 \\
\hline BDGGOOD & 1 if surrounding buildings are in good condition & 0.33 & 0.49 \\
\hline BDGEXC & 1 if surrounding buildings are in excellent condition & 0.12 & 0.33 \\
\hline PARKG & 1 if building has private parking & 0.40 & 0.49 \\
\hline YEAR & $\begin{array}{l}\text { Year in which the building was originally } \\
\text { constructed. } 1 \text { if before } 1950 \text { to } 8 \text { if after } 1985\end{array}$ & 3.07 & 0.10 \\
\hline
\end{tabular}


This same method was employed in the selection of housing units. The households were randomly selected if more than one household lived in the unit. If only one household lived in the unit, that household was interviewed. Public houses and commercial renters were excluded from the sample because of the high public subsidies, and distortions of rents prevalent in these.

Information was collected on the structural attributes (number of rooms, toilets, type of building, parking, number of flats, year of original construction, and number of floors), and environmental attributes of the houses (distance to a major market center, the central business district, and place of work, condition of streets, and surrounding buildings).

\section{ESTIMATION}

The functional form in equation (5) is used to estimate the impact of housing attributes on the price of rental houses in Lagos. We expect NROOM, KITCH, FENCE, BATH, YEAR, ELECOC, ELECST, WATOC, WATST, PAINTFL, PAINTPT, PARKG, STRFAIR, STRGOOD, STREXC, BDGFAIR, BDGOOD, BDGEXC, and PARKG to be positively related to the cost of housing in Lagos because these are considered utility-generating attributes.

The year variable measures the age of the house using the period of construction instead of actual age of the building, because the actual year of construction was difficult to obtain in many cases. The newer the house, the higher is the number assigned, hence a positive value on the coefficient of YEAR implies a negative relationship between rent and the age of the house.

The omitted variables for conditions of streets and surrounding buildings are poor conditions of streets and surrounding buildings. Positive values on these variables imply that rent on the house increases as one moves from a building with poor streets or surrounding buildings to a similar building with fair, good or excellent streets or surrounding buildings. For painting, partially painted and fully painted buildings are compared to unpainted buildings.

A positive sign on KITCH, PARKG, or FENCE implies that rent increases due to the availability of a private kitchen, parking space, or fence.

BLDRM, BLDFLT, CRIME, CBD, and WORK are expected to be negatively related to rental rate. We expect, from theory, that the farther away a house is from the center of business activity or employment, the lower the rent will be on the house.

Since crime is noxious, a household may be willing to pay a higher rent to live in an area with low crime rate. Due to the lack of data on the number of 
crimes committed in the different areas of Lagos, a ranking of all the areas is used as a proxy for crime rate, with high values representing high crime rates.

For the type of buildings variables, we compared rooming houses and multiflat houses to single family houses. Negative signs on these imply that rent decreases as one moves from single-family houses to rooming or multi-flat houses. It is assumed that households prefer single-family homes because of the privacy they provide.

The coefficients of MKT, NFLOOR, and NFLAT were not signed a priori. In the case of MKT, we realize that while a house located near a major market center provides easy access to shopping and transportation (as is the case in Nigeria), it may also be accompanied with high noise, pollution, and congestion levels. Access to shopping and transportation implies a negative sign on MKT, while high noise, pollution, and congestion levels imply a positive sign.

NFLOOR and NFLAT may represent better quality housing, but they may also represent overcrowding. The more floors or flats in the building, the greater the number of households sharing facilities.

\section{RESULTS AND ANALYSIS}

Table 3 presents the results of the regression. The $R^{2}$ for the regression is 0.97 , and is significant at the 0.01 level, with F-value of 1035.94. The log likelihood function for this regression is maximized for the values of $\lambda$ and $\mu$ equal to 0.1 , and 0 respectively, implying that the Lagos housing market is not homogeneous.

Thirteen of the twenty-six variables are significant, at least at the 10 percent level. All of the significant, a priori signed variables have the expected signs. NROOM, BATH, BDGRM, BDGFLT, ELECOC, ELECST, NFLAT, WATST, KITCH, CRIME, PAINTFL, and BDGEXC have the expected signs. Of the a priori signed variables, only FENCE, STRFAIR, and PARKG do not have the expected signs, although none is significant.

Implicit prices for housing characteristics in our sample are also shown in Table 3. These prices are calculated using the formula:

$$
\partial R / \partial Z_{i}=P_{i}=\beta_{i} Z_{i}^{(\mu-1)} R_{i}^{(1-\lambda)}
$$

Where $\partial \mathrm{R} / \partial \mathrm{Z}_{\mathrm{i}}$ is a change in monthly contract rent with respect to a unit change in characteristic $i_{1} P_{i}$ is the hedonic price of characteristic $i, Z_{i}$ is the mean value of characteristic $i, R$ is the mean value of the contract rent, $\beta_{i}$ is the coefficient of 
TABLE 3

Hedonic Regression Result for the Maximized Log Likelihood Function, and Estimated Implicit Prices for Housing Attributes

\begin{tabular}{|c|c|c|c|}
\hline Variables & Coefficient & $\begin{array}{c}\text { Absolute } \\
\text { t-value }\end{array}$ & $\begin{array}{l}\text { Hedonic prices evaluated } \\
\text { at the mean monthly rent }\end{array}$ \\
\hline$\overline{\mathrm{KITCH}}$ & $0.021 *$ & 2.860 & 4.25 \\
\hline NROOM & $0.163 *$ & 29.683 & 12.88 \\
\hline BATH & $0.038 *$ & 6.747 & 9.59 \\
\hline YEAR & 0.001 & 0.240 & 0.07 \\
\hline NFLOOR & 0.004 & 0.607 & -0.41 \\
\hline FENCE & -0.002 & 0.486 & 0.99 \\
\hline NFLATS & $0.011 *$ & 2.770 & 1.00 \\
\hline BDGRM & $-0.208 *$ & 13.801 & -42.09 \\
\hline BDGFLT & $-0.126^{*}$ & 12.239 & -25.49 \\
\hline ELECOC & $0.031 *$ & 3.990 & 6.21 \\
\hline ELECST & $0.044^{*}$ & 4.758 & 8.90 \\
\hline WATOC & 0.003 & 0.839 & 0.61 \\
\hline WATST & $0.012 * *$ & 2.402 & 2.40 \\
\hline PAINTPT & 0.002 & 0.297 & 0.41 \\
\hline PAINTFL & $0.014^{* * *}$ & 1.949 & 2.83 \\
\hline PARKG & -0.003 & 0.849 & -0.61 \\
\hline MKT & $0.023 *$ & 4.958 & 4.65 \\
\hline CBD & -0.017 & 1.256 & -0.40 \\
\hline WORK & -0.002 & 1.150 & -0.50 \\
\hline STRFAIR & -0.005 & 1.028 & -1.01 \\
\hline STRGOOD & 0.002 & 0.445 & 0.41 \\
\hline STREXC & 0.10 & 1.210 & 2.02 \\
\hline BDGFAIR & 0.009 & 1.639 & 1.81 \\
\hline BDGGOOD & 0.008 & 1.294 & 1.62 \\
\hline BDGEXC & $0.054^{*}$ & 4.543 & 10.93 \\
\hline CRIME & $-0.003 * *$ & 2.462 & -0.61 \\
\hline $\ln L$ & -1946 & & \\
\hline F-value & 1035.94 & & \\
\hline $\mathrm{R}^{2}$ & 0.97 & & \\
\hline$\lambda$ & 0.1 & & \\
\hline$\mu$ & 0 & & \\
\hline Number & 772 & & \\
\hline
\end{tabular}

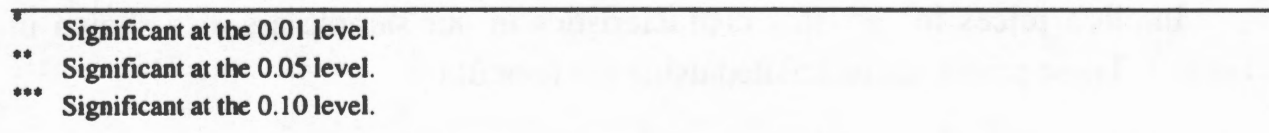

characteristic $i$, and $\mu$ is the power transformation parameter on the independent variable.

Very few studies have been undertaken using African cities to enable us to compare our results with other findings; however, the few that have been undertaken show results similar to ours. Megbolugbe $(1986,1989)$, using a Jos sample, 
obtained the maximized log likelihood function for the value of $\lambda=-0.2$. He constrained the values of the power transformations on all the variables to be equal. Our study uses different transformations for the independent and dependent variables.

\section{STRUCTURAL ATTRIBUTES}

The structural attributes of housing appear to be more important than other factors in determining the rental rates of houses in the market studied. Of sixteen structural variables used, ten are significant. The magnitudes of the estimates are generally higher for the structural characteristics than for the environmental characteristics. $\mathrm{Li}$ and Brown (1980), using data from Boston, also obtained stronger results for structural attributes compared to environmental attributes.

KITCH, NROOM, BATH, NFLAT, ELECOC, ELECST, PAINTFL and WATST are all positive and significant, indicating that their presence increases the rental rate of housing. An increase in the number of rooms increases monthly

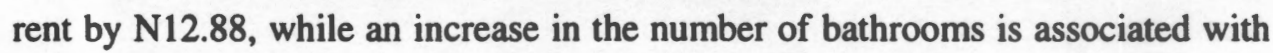
an $\mathrm{N} 9.59$ increase in rent.

Electricity and water variables consider changes from no electricity and pipeborne water to an occasional or steady supply. A change from unavailability of electricity to occasional supply increases monthly rent by N6.21, while a change to steady supply increases rent by N8.90. Steady supply of pipe-borne water to the housing unit is associated with $\mathrm{N} 2.40$ increase in monthly rent compared to lack of water supply.

The result indicates that the availability of private kitchens increases monthly rent in Lagos by N4.25, compared to a shared kitchen. PAINTFL indicates that renters are willing to pay N2.83 more per month, on the average, to live in fully painted houses instead of unpainted ones. This may be so because most of the houses are built with cement blocks, not wood or bricks.

BDGRM and BDGFLT are negatively related to housing rent, indicating that rents are, on the average, lower in rooming and multi-flat buildings than in single family houses. Compared to single-family houses, monthly rents on multi-flat houses are lower by $\mathrm{N} 25.49$, and on rooming houses by $\mathrm{N} 42.09$.

Some studies in developed countries include air conditioning and heating as structural variables. These were not included here because none of the houses we surveyed had heating units or air conditioners. Tenants who did own air conditioners had installed their own window units, and the cost was not included in the rents. 


\section{ENVIRONMENTAL ATTRIBUTES}

The result of the study indicates the relatively weaker effects of environmental attributes of a house on rental rates in Lagos. Ten environmental attributes were included in this study, only three of which are significant. The condition of the street on which the building is located and the conditions of buildings at the location are measured by the STR and BDG variables, respectively. These are all compared to poor conditions. Only BDGEXC is significant and has the expected sign. Location in areas with surrounding buildings in excellent condition is associated with $\mathrm{N} 10.93$ increases in monthly rent.

The distance to a major market center, MKT, is positively related to rental rate. This is not surprising, since the average distance to major market centers in Lagos is short. Moreover, households seem to consider the disadvantages of living close to a major market center (pollution, congestion, and noise) to outweigh the advantage (access). An increase in the distance to a major market center increases monthly rent by $\mathrm{N} 4.65$ per kilometer. Since the average distance to a major market center is $\mathbf{1 . 9 4}$ kilometers, the average increase in rent is less than ten naira.

Distance to the central business district (CBD) has been found to be significantly negative in some previous studies such as the one by Arimah (1992). This study finds it to be insignificant at the 5 percent level. This may be due to the fact that only one CBD was used in this study, while Lagos is a multi-CBD city. Megbolugbe $(1986,1989)$ also found it not to be significant in his Jos study.

The perceived crime rate at the location of the house is negatively related to rental rate in Lagos, although the impact of crime rate is very small. An increase in the ranking of the location by one unit leads to a N0.61 decrease in monthly rent.

\section{SUMMARY AND POLICY IMPLICATIONS}

This paper studies the impact of structural and environmental characteristics of a house on rental rates in an urban African city. The results of hedonic analysis of Lagos, Nigeria, show that the characteristics of a house do affect rental rates. The direction of impact depends on whether the characteristic is viewed as a good or bad. An increase in the number of rooms, for instance, increases rents significantly, while an increase in the crime rate at the location of the house reduces rents. Our results also show that structural characteristics tend to have larger impacts on rental rate than environmental characteristics in our area of study. 
These results are basically similar to results obtained using data from developed countries, for instance, in Dinan and Miranowski (1989). If so, it is possible that studies based on developed countries can be adapted to suit African countries and then used to formulate housing policies in these countries.

The importance of the hedonic technique for policy purposes have been discussed by Megbolugbe (1986, 1989), Follain and Jimenez (1985a), Murray (1980), and De Borger (1987). The governments in Nigeria provide public housing. Hedonic analysis can provide estimates of housing attributes that can be used to design appropriate projects. Two uses are briefly discussed here. Hedonic analysis provide important information for determining the type of housing to build, and the rental rates on the houses.

First, to determine the type of house, the hedonic estimates of the housing characteristics for similar cost designs are obtained. These are then used in the estimated utility function for the sample population. The design that provides the highest level of utility is the optimal design (Follain and Jimenez 1985a). Separate estimates could be obtained for various segments of the market-for instance, high-income, middle-income, and low-income housing and specific housing types targeted toward them, based on utility maximization.

Second, to determine the rental rate, the utility function of the household as a function of both the housing and non-housing bundles consumed is evaluated, subject to the household's budget constraint. The transformed utility function for rent as a function of the housing characteristics is evaluated to derive the household's willingness to pay for the housing bundle.

The different bundles can be priced differently, depending on the composition of each bundle. A hedonic approach can be used to obtain the implicit prices of the characteristics in the bundle. Using a segmented data set, it is possible to price-discriminate using the hedonic approach to determine rent that reflects the marginal willingness of the various households groups to pay. For instance, if high income households are willing to pay more for rooms, or lot size, then their rent will reflect that willingness.

Some additional uses of the hedonic analysis have been discussed in the literature. Megbolugbe (1989) and De Borger (1987) provide a detailed discussion of program benefit estimation. While the hedonic approach has been shown to be applicable to Africa, as well as to developed countries, it has not been very commonly used to the analysis of African housing markets. The major problem is the general lack of availability of data on housing markets in Africa. 


\section{REFERENCES}

Adeniyi, E.O. "Housing In Nigerian National Development." Nigerian Journal of Economics and Social Studies 14(1972): 315-326.

Arimah, B. C. "Hedonic Prices and the Demand for Housing Attributes in a Third World City: The Case of Ibadan, Nigeria." Urban Studies 29, No. 5(1992): 639-651.

Awan, K., Odling-Smee, J.C., and Whitehead, C.M.E. "Household Attributes and the Demand For Private Rental Housing." Economica 49(1982): 183-200.

Blomquist, G. "Valuing Urban Lakeview Amenities Using Implicit and Contingent Markets." Urban Studies 25(1988): 333-340.

Blomquist, G., and Worley, L. "Specifying the Demand for Housing Characteristics: The Exogeneity Issue." In Diamond, D.B., and Tolley, G.S. (ed.). The Economics of Urban Amenities (1982): 69-88.

Box, G.E., and Cox, D.R. "An Analysis of Transformations." Journal of the Royal Statistical Society, series B. 26(1964): 211-252.

Cassel, E., and Mandelsohn, R. "The Choice of Functional Forms For Hedonic Price Equations: Comment." Journal of Urban Economics 18(1985): 135142.

De Borger, B. "Composite Commodities, Housing Characteristics and The Hicksian Surplus Measures of Welfare Change." Regional Science and Urban Economics 17(1987): 475-494.

Dinan, T.M., and Miranowski, J.A. "Estimating the Implicit Price of Energy Efficiency Improvements in the Residential Housing Market: A Hedonic Approach." Journal of Urban Economics 25(1989): 52-67.

Dubin, R.A., and Sung, C. "Specification of Hedonic Regressions: Non-nested Tests on Measures of Neighborhood Quality." Journal of Urban Economics 27(1990): 97-110.

Federal Ministry of National Planning. "Guideline for the Fourth National Development Plan, 1981-1985" 95(1985): 59-80.

Follain, J.R., and Jimenez, E. "Estimating the Demand for Housing Characteristics." Regional Science and Urban Economics 15(1985a): 77-107.

Follain, J.R., and Jimenez, E. "The Demand for Housing Characteristics in Developing Countries." Urban Studies 22(1985b): 421-432.

Follain J.R., Lim, G., and Renaud, B. "The Demand for Housing in Developing Countries: The Case of Korea." Journal of Urban Economics 7(1980): 315336.

Goodman, A.C., and Kawai, M. "Functional Form, Sample Selection and Housing Demand." Journal of Urban Economics 20(1986): 155-167. 
Halvorsen, R., and Pollakowski, H.O. Choice of Functional Form for Hedonic Price Equations." Journal of Urban Economics 10(1981): 37-49.

Kain, J., and Quigley, J. "Measuring the Value of Housing Quality." Journal of American Statistical Association 65(1970): 532-548.

Lagos State Ministry of Economic Development and Establishment. Statistical Survey of Lagos State. November/December, 1976.

Lancaster, K. J. "A New Approach to Consumer Theory." Journal of Political Economy 74(1966): 132-157.

Li, M.M., and Brown, J.H. "Micro-Neighborhood Externalities and Hedonic Housing Prices." Land Economics 56, 2(May 1980): 125-141.

Linneman, P. "Some Empirical Results on the Nature of the Hedonic Price Function for the Urban Housing Market," Journal of Urban Economics 8(1980): 47-68.

Lubell, H. "Third World Urbanization and International Assistance." Urban Studies 21(1984): 1-13.

Malpezzi, S. and Mayo, K. "Housing Cost and Housing Tenure in Developing Countries." Journal of Development Economics 25(1987): 197-220.

Megbolugbe, I. F. "Econometric Analysis of Housing Trait Prices in a Third World City." Journal of Regional Science 26, No. 3(1986): 533-547.

Megbolugbe, I. F. "A Hedonic Index Model: The Housing Market of Jos, Nigeria." Urban Studies 26(1989): 486-494.

Michaels, R.G., and Smith, V.K. "Market Segmentation and Valuing Amenities With Hedonic Models: The Case of Hazardous Waste Sites." Journal of Urban Economics 28, 2(September 1990): 223-242.

Murray, M. P., "Tenant Benefit In Alternative Federal Housing Programmes." Urban Studies 17(1980): 25-34.

Okpala, D. C. (1987) "Received Concepts and Theories in African Urbanization Studies and Urban Management Strategies: A Critique." Urban Studies 24(1987): 137-150.

Onokerhoraye, A. G. "Urban Environmental Problems and Planning Strategies in Tropical Africa." The Annals of Regional Science 10, No. 2(1976): 24-35.

Palmquist, R. B. "Estimating the Demand for the Characteristics of Housing." Review of Economics and Statistics 66(1984): 394-404.

Rosen, S. "Hedonic Prices and Implicit Markets: Product Differentiation in Pure Competition." Journal of Political Economy 82(1974): 35-55. 